\title{
Kekhasan Pola Argumentasi Tajuk Rencana Kompas.id
}

\author{
Pilipus Wai Lawet \\ Program Magister Pendidikan Bahasa Indonesia, Universitas Sanata Dharma, Yogyakarta
}

\author{
*Pelipus Wai Lawet: \\ Program Magister Pendidikan \\ Bahasa Indonesia; \\ Universitas Sanata Dharma, \\ Yogyakarta; Email: \\ lawetj209@gmail.com
}

\begin{abstract}
Abstrak: Argumentasi merupakan salah satu bentuk komunikasi yang digunakan penulis untuk menyakinkan atau membujuk pembaca. Pola penulisan argumentasi pada tajuk rencana setiap media massa tentunya memiliki kekhasannya masing-masing. Penelitian ini ditujukan untuk menemukan kekhasan pola argumentasi dalam tajuk rencana media daring Kompas.id. Pengumpulan data dalam penelitian ini memanfaatkan metode simak yang diterapkan melalui teknik baca dan catat. Dalam analisis data, peneliti menggunakan analisis kontain yang diterapkan melalui beberapa langkah, yakni inventarisasi, identifikasi, klasifikasi, dan deskripsi data. Berdasarkan hasil analisis yang dilakukan, ditemukan empat pola argumentasi dalam tajuk rencana Kompas.id, yakni: (1) pola pernyataan posisi-data; (2) pola pernyataan posisi-data-jaminan; (3) pola pernyataan posisi-data 1- data 2jaminan; dan (4) pola data-pernyataan posisi.
\end{abstract}

Kata Kunci: Pola argumentasi, tajuk rencana Kompas.id.

Abstract: Argumentation is a form of communication that writter used to convince or persuade the reader. Certainly, each mass media had its own argumentation pattern to write editorial. This research is aims to describe the patterns of argumentation in Kompas.id editorials. The data collection of this research utilize the observation method which is applied through reading and note-taking techniques. In data analisys, content analisys is used which is applied in several way, name inventory, identification, clasification, and data description. The result shows that patterns of arguments can be differetiated into four, namely (1) Claim-Data; (2) Claim-Data-warrant; (3) Claim-Data 1Data2-Warrant; (4) Data - Claim.

Key word: patterns of arguments, Kompas.id. editorial.

\section{Pendahuluan}

Media massa merupakan salah satu institusi sosial yang memiliki fungsi sangat penting dalam memberikan informasi yang berguna bagi khalayak. Menurut UU No. 40 tahun 1999 pasal 3 ayat 1, ada empat fungsi utama media massa, yaitu media informasi, media pendidikan, hiburan, dan kontrol sosial. Sebagai media informasi, media massa memuat atau disiarkannya hasil kerja wartawan (Hikmat, 2018). Hasil kerja tersebut berupa laporan atau liputan mengenai peristiwa-peristiwa yang sedang terjadi, ide-ide, opini-opini yang mutakhir di dunia yang lazim disebut berita. Selain berita, ada halaman khusus yang disediakan untuk memberikan ruang bagi redaksi untuk menyampaikan ide, pemikiran, opini dan tanggapan media massa yang bersangkutan terhadap berita mengenai isu-isu aktual yang terjadi di masyarakat. Karangan atau tulisan itu sering disebut dengan editorial atau tajuk rencana (Wiyanti \& Dinihari, 2017).

Tajuk rencana tak lain adalah mahkota halaman keredaksian (Siregar, 2002). Sebagai mahkota, tajuk rencana tentunya menjadi kekuatan dan kelemahan sebuah media (Rivers, 2004: 240) yang memberikan gambaran karakteristik media massa tertentu. Menurut Roni \& Anggara (2015) karakter atau identitas sebuah media massa dapat dilihat dalam tajuk rencana yang meliputi beberapa hal seperti motto, ukuran kertas, gaya penulisan, gaya bahasa, isi pemberitaan (Padiatra, 2018). Selain itu, melalui rubrik tajuk rencana yang secara eksplisit disajikan visi misi oleh media kepada pembaca (Siregar, 2002). Penyajian secara eksplisit tersebut dimaksudkan agar pembaca secara gamblang dapat memperoleh pemahaman tentang pandangan atau pikiran yang hendak diungkapkan oleh media massa terkait dengan masalah aktual 
yang terjadi di masyarakat.

Argumentasi menjadi sebuah hal yang sangat esensial dalam penulisan tajuk rencana. Menurut Weston (2007), keesensialan argumentasi tersebut disandarkan pada dua alasan, yakni argumentasi merupakan sebuah usaha mencari tahu pandangan mana yang lebih baik dari yang lain dan argumen dijabarkan sebagai cara seseorang menjelaskan dan mempertahankan suatu gagasan. Senada dengan hal itu, Keraf (2007) juga menyatakan bahwa argumentasi merupakan dasar yang paling fundamental dalam ilmu pengetahuan. Melalui argumentasi seseorang dapat menunjukkan pernyataan-pernyataan (teori-teori) yang dikemukakan benar atau tidak dengan mengacu pada fakta atau bukti-bukti yang ditunjukkan. Sementara itu, Douglas Walton (2013) menyatakan bahwa argumentasi merupakan istilah yang digunakan untuk merujuk pada seluruh aktivitas pemberian alasan untuk mendukung atau mengkritik klaim yang dipertanyakan.

Argumen yang berkualitas dapat dilihat dari pola-pola argumen yang digunakan dalam tajuk rencana. Pola argumen dapat diidentifikasi melalui penggunaan elemen-elemen dalam penulisan tajuk rencana. Toulmin, dkk. (1979), mengemukakan bahwa terdapat enam elemen yang dapat digunakan untuk mengembangkan argumen yang berkualitas, yaitu: Pertama, pernyataan posisi. Elemen pernyataan posisi merupakan pernyataan tegas yang diletakan di awaldan dapat diterima secara umum dengan maksud mendasari sebuah pemikiranyang dapat ditunjukan dengan baik sehingga sesuatu yang belum diketahui menjadi diketahui. Kedua, data atau fakta. Elemen ini disebut sebagai alasan yang mendukung pernyataan posisi. Rani, dkk (2006) menyatakan bahwa alasan adalah bukti-bukti yang bersifat khusus yang diperlukan untuk mendukung pernyataan. Alasan dapat berupa data statistik, contoh, ilustrasi, observasi eksperimental, dan materi ilmu pengetahuan umum, maupun pengujian. Ketiga, jaminan/warrants (J). Elemen jaminan merupakan pernyataan yang menghubungkan pernyataan posisi dengan dat sehingga membentuk suatu alasan utama. Keempat, dukungan. Elemen dukungan merupakan generalisasi yang dibuat secara ekplisit yang diandalkan untuk membangun kepercayaan pembaca. Pemberi argument setidaknya memberikan sesuatu yang menunjukkan bahwa jaminan yang telah dikemukakan dapat berdiri sendiri dengan dukungan. Kelima, modalitas. Elemen modalitas adalah pernyataan berupa sikap, nada, dan gaya argumen yang dilakukan untuk memengaruhi pembaca argumen. Menurut Toulmin, dkk (1979) modalitas ini menunjukan seberapa kuatnya argumen mengingat ketersediaan elemen-elemen yang dikemukakan untuk mendukung pernyataan posisi. Modalitas biasanya berbentuk kata keterangan seperti perlunya, pastinya, tentunya, biasanya, normalnya, kemungkinan besar, rupanya, dan lain-lain. Keenam, pengecualian. Elemen pengecualian. Elemen pengecualian merupakan persiapan ketika pernyataan posisi mendapat sanggahan atas pengecualian terhadap pernyataan posisi.

Lebih lanjut, Setyaningsih (2016) mengemukakan bahwa elemen-elemen ini saling berhubungan satu sama lain dan kehadiran setiap elemen pada argumen bersinergi dan saling menguatkan. Ketidakhadiran satu elemen berpotensi untuk melemahkan argumen. Oleh karena itu, dapat dikatakan bahwa penggunaan enam elemen argumen dapat menjadikan kualitas dan ketajaman argumen menjadi sangat kuat dalam tulisan tajuk rencana. Semakin lengkap elemen yang digunakan penulis dalam membangun argumentasi, semakin kuat dan tidak terbantahkan argumentasinya.

Berdasarkan uraian tersebut, penulisan artikel ini difokuskan pada argumentasi dalam tajuk rencana media daring Kompas.id. Adapun tujuan penelitian ini adalah untuk mendeskripsikan kekhasan pola argumentasi tajuk rencana pada media Kompas.id. Hal ini menjadi penting mengingat tajuk rencana merupakan napas yang menghidupkan dan menjadi ciri khas setiap media massa.

\section{Metode Penelitian}

Penelitian ini menggunakan pendekatan kualitatif dengan metode penelitian deskriptif. Moleong (2017) bahwa penelitian kualitatif adalah penelitian yang bermaksud untuk memahami fenomena tentang apa yang dialami oleh subjek penelitian, misalnya perilaku, persepsi, motivasi, tindakan, dan lain-lain secara holistik dan dengan cara deskripsi dalam bentuk kata-kata dan bahasa pada suatu konteks khusus yang alamiah dan dengan memanfaatkan berbagai metode alamiah. Data penelitian ini berupa paragraf tajuk rencana media daring Kompas.id yang mengandung argumentasi. Sumber data penelitian ini berupa 53 teks tajuk rencana media daring Kompas.id edisi Januari 2019.

Prosedur pengumpulan data penelitian ini adalah teknik baca dan catat (Sudaryanto, 2015). 
Analisis data dalam penelitian ini memanfaatkan metode analisis konten Huberman. Langkahlangkah yang dilakukan peneliti dalam menganalisis konten, yakni (1) membaca harian media daring Kompas.id, (2) mengoleksi dan mengklasifikasi teks tajuk rencana yang akan dianalisis, (3) memberikan kode pada tajuk rencana yang akan dianalisis, (4) menandai pola argumentasi dalam tajuk rencana, (5) merekam data ke dalam tabel analisis, (6) mengelompokkan data berdasarkan pola argumentasi, (7) memberikan kode, dan (8) melakukan analisis. Instrumen kunci penelitian ini adalah peneliti sendiri karena peneliti berperan dalam menetapkan fokus penelitian, memilih sumber data, melakukan pengumpulan data, menganalisis data, menafsirkan data, serta membuat kesimpulan atas temuannya.

\section{Hasil dan Pembahasan}

Berdasarkan hasil identifikasi dan klasifikasi data ditemukan bahwa terdapat empat pola argumentasi yang digunakan dalam penulisan tajuk rencana media daring Kompas.id, yakni pola pernyataan posisi-data (PP-D), pola pernyataan posisi-data-jaminan (PP-D-J), pola pernyataan posisi-data1-data2-jaminan (PP-D1D2-J), Pola data-pernyataan posisi (D-PP). Keempat pola argumentasi tersebut akan dibahas secara terperinci sebagai berikut.

\section{Pola Pernyataan Posisi-Data 1 (PP-D)}

Berdasarkan hasil analisis, ditemukan pola argumentasi pada paragraf-paragraf argumentif yang terdiri atas komponen pernyataan posisi (PP) dan komponen data (D). Pola ini dimulai dengan komponen PP yang diikuti dengan komponen $\mathrm{D}$ untuk mendukung PP tersebut. Penulisan tajuk rencana dengan pola tersebut paling banyak dijumpai pada media daring Kompas.id. Menurut Setyaningsih (2016) pola argumentasi yang didahului dengan komponen PP dan didukung dengan komponen D dapat dikategorikan ke dalam pola deduktif. Pola tersebut dapat dilihat pada paragraf argumentasi tajuk rencana berikut.

\begin{tabular}{|c|c|c|c|}
\hline $\begin{array}{l}\text { Paragraf } \\
\text { Argumentasi }\end{array}$ & \multicolumn{2}{|c|}{$\begin{array}{l}\text { Komponen } \\
\text { Argumentasi }\end{array}$} & $\begin{array}{l}\text { Pola } \\
\text { Argum }\end{array}$ \\
\hline $\begin{array}{l}\text { Persoalan } \\
\text { yang perlu } \\
\text { menjadi } \\
\text { perhatian } \\
\text { bersama di } \\
\text { tahun politik } \\
\text { ini adalah } \\
\text { memudarnya }\end{array}$ & $\begin{array}{l}\text { Persoala } \\
\mathrm{n} \text { yang } \\
\text { perlu } \\
\text { menjadi } \\
\text { perhatian } \\
\text { bersama } \\
\text { di tahun } \\
\text { politik }\end{array}$ & $\begin{array}{l}\text { Perny } \\
\text { ataan } \\
\text { Posisi }\end{array}$ & PP-D \\
\hline
\end{tabular}

\begin{tabular}{|c|c|c|}
\hline $\begin{array}{l}\text { solidaritas } \\
\text { bangsa. Jajak } \\
\text { pendapat Kom } \\
\text { pas di } \\
\text { pengujung } \\
\text { tahun } 2018 \\
\text { merekam } \\
\text { adanya } \\
\text { kecemasan } \\
\text { yang tinggi } \\
\text { dari } \\
\text { masyarakat } \\
\text { akibat } \\
\text { maraknya } \\
\text { berita bohong } \\
\text { di media } \\
\text { sosial } \\
\text { (Kompas, } \\
\text { 31/12/2018). } \\
\text { Mayoritas } \\
\text { responden pun } \\
\text { khawatir } \\
\text { Pemilu 2019 } \\
\text { dapat } \\
\text { menimbulkan } \\
\text { pertengkaran } \\
\text { di lingkungan } \\
\text { sekitar atau } \\
\text { mengurangi } \\
\text { rasa } \\
\text { kebersamaan } \\
\text { di lingkungan } \\
\text { sekitar. }\end{array}$ & $\begin{array}{l}\text { ini } \\
\text { adalah } \\
\text { memudar } \\
\text { nya } \\
\text { solidarita } \\
\text { s bangsa. } \\
\\
\text { Jajak } \\
\text { pendapat } \\
\text { Kompas } \\
\text { di } \\
\text { pengujun } \\
\text { g tahun } \\
\text { 2018 } \\
\text { merekam } \\
\text { adanya } \\
\text { kecemasa } \\
\text { n yang } \\
\text { tinggi } \\
\text { dari } \\
\text { masyarak } \\
\text { at akibat } \\
\text { marakny } \\
\text { a berita } \\
\text { bohong } \\
\text { di media } \\
\text { sosial } \\
\text { (Kompas, } \\
\text { 31/12/20 } \\
\text { 18). } \\
\text { Mayorita } \\
\text { s } \\
\text { responde } \\
\text { n pun } \\
\text { khawatir } \\
\text { Pemilu } \\
2019 \\
\text { dapat } \\
\text { menimbu } \\
\text { lkan } \\
\text { pertengk } \\
\text { aran di } \\
\text { lingkung } \\
\text { an sekitar } \\
\text { atau } \\
\text { mengura } \\
\text { ngi rasa } \\
\text { kebersam } \\
\text { aan di } \\
\text { lingkung } \\
\text { an } \\
\text { sekitar. }\end{array}$ & Data \\
\hline
\end{tabular}

Kalimat pertama pada contoh di atas adalah komponen PP. Kalimat kedua merupakan komponen $\mathrm{D}$ yang memberikan dukungan pada 
PP. Komponen PP merupakan pandangan atau pendirian media Kompas.id terkait fenomena yang terjadi di masyarakat. Hal ini sejalan dengan apa yang dikatakan Toulmin (1979) bahwa pernyatan pendapat merupakan pendirian penulis. Penulis berpandangan bahwa pudarnya solidaritas bersama menjadi sebuah fenomena yang harus diperhatikan bersama. Pernyataan posisi penulis tersebut memiliki kadar ketajaman yang tinggi karena berdasarkan pada fakta yang benar-benar terjadi (Robertshaw \& Campbell, 2013). Sementara itu, untuk mendukung komponen PP, penulis menggunakan data dari Jajak Pendapat Kompas tahun 2018 yang memiliki kadar ketajaman tinggi karena berupa fakta empiris dari hasil jajak pendapat. Hal ini selaras dengan pernyataan Seyler (2019) bahwa data dengan kadar ketajaman tinggi adalah data berupa fakta empiris misalnya hasil penelitian, hasil observasi, dan data statistik.

Dari pengamatan peneliti, paragraf argumentatif yang disusun dengan pola PP-D banyak ditemukan dalam paragraf-paragraf argumentatif tajuk rencana. Kenyataan demikian membuktikan bahwa sebagian besar tulisan argumentatif dalam tajuk rencana tersebut masih rendah kualitas argumennya. Menurut Setyaningsih (2016) komponen PP dalam paragraf argumentatif yang ideal tidak boleh berhenti hanya dengan hadirnya komponen $\mathrm{D}$ yang menjelaskan lebih lanjut komponen PP tersebut.

\section{Pola Pernyataan Posisi-Data-Jaminan (PP- D-J)}

Pola argumentasi tajuk rencana ini terdiri atas komponen pernyataan posisi (PP), data (D), dan jaminan (J). Pola ini diawali dengan komponen PP yang terdapat pada awal awal kalimat kemudian diikuti dengan komponen D sebagai alasan yang mendukung pernyataan posisi. Selanjutnya, pada kalimat terakhir terdapat komponen $\mathrm{J}$ yang menghubungkan komponen PP dan komponen D. Pola tersebut dapat dilihat pada paragraf argumentasi tajuk rencana berikut.

\begin{tabular}{|c|c|c|c|}
\hline $\begin{array}{l}\text { Paragraf } \\
\text { Argumentasi }\end{array}$ & \multicolumn{2}{|c|}{$\begin{array}{l}\text { Komponen } \\
\text { Argumentasi }\end{array}$} & $\begin{array}{l}\text { Pola } \\
\text { Argum } \\
\text { entasi }\end{array}$ \\
\hline $\begin{array}{l}\text { Isu korupsi, } \\
\text { perlindungan } \\
\text { hak asasi } \\
\text { manusia, dan } \\
\text { penyelesaian } \\
\text { pelanggaran } \\
\text { HAM pada }\end{array}$ & $\begin{array}{l}\text { Isu } \\
\text { korupsi, } \\
\text { perlindun } \\
\text { gan hak } \\
\text { asasi } \\
\text { manusia, } \\
\text { dan }\end{array}$ & $\begin{array}{l}\text { Perny } \\
\text { ataan } \\
\text { Posisi }\end{array}$ & PP-D-J \\
\hline
\end{tabular}

\begin{tabular}{|c|c|c|}
\hline $\begin{array}{l}\text { masa lalu } \\
\text { adalah isu } \\
\text { yang ingin } \\
\text { didengar } \\
\text { publik. } \\
\text { Mengapa } \\
\text { korupsi? } \\
\text { Sudah } \\
\text { menjadi fakta } \\
\text { bahwa } \\
\text { Indonesia } \\
\text { bergelimang } \\
\text { korupsi. } \\
\text { Calon } \\
\text { presiden } \\
\text { Prabowo } \\
\text { Subianto di } \\
\text { Singapura } \\
\text { mengatakan, } \\
\text { korupsi di } \\
\text { Indonesia, } \\
\text { seperti } \\
\text { kanker, telah } \\
\text { memasuki } \\
\text { stadium } \\
\text { empat. }\end{array}$ & $\begin{array}{l}\text { penyeles } \\
\text { aian } \\
\text { pelangga } \\
\text { ran HAM } \\
\text { pada } \\
\text { masa lalu } \\
\text { adalah } \\
\text { isu yang } \\
\text { ingin } \\
\text { didengar } \\
\text { publik. } \\
\text { Mengapa } \\
\text { korupsi? } \\
\text { Sudah } \\
\text { menjadi } \\
\text { fakta } \\
\text { bahwa } \\
\text { Indonesia } \\
\text { bergelim } \\
\text { ang } \\
\text { korupsi. } \\
\\
\text { Calon } \\
\text { presiden } \\
\text { Prabowo } \\
\text { Subianto } \\
\text { di } \\
\text { Singapur } \\
\text { a } \\
\text { mengatak } \\
\text { an, } \\
\text { korupsi } \\
\text { di } \\
\text { Indonesia } \\
\text {, seperti } \\
\text { kanker, } \\
\text { telah } \\
\text { memasuk } \\
\text { i stadium } \\
\text { empat. }\end{array}$ & $\begin{array}{l}\text { Jamin } \\
\text { an }\end{array}$ \\
\hline
\end{tabular}

Komponen pernyataan posisi (PP) yang diungkapkan penulis dalam data 2 tersebut di atas berkaitan dengan isu korupsi, perlindungan hak asasi manusia, dan penyelesaian pelanggaran HAM pada masa lalu adalah isu yang ingin didengar publik. Komponen PP tersebut dapat dikategorikan PP dengan ketajaman sedang karena berupa pernyataan posisi penulis dengan latar belakang informasi (Robertshaw \& Campbell, 2013). Komponen data (D) yang digunakan penulis berupa data faktual dimana bahwa Indonesia yang bergelimang korupsi sudah menjadi rahasia publik. Penulis hanya 
menggunakan komponen data (D) berupa pandangan umum untuk mendukung pernyataan posisi (PP) tanpa disertai bukti-bukti berupa data statistik, contoh, ilustrasi, penalaran, observasi eksperimental, dan materi pengetahuan umum, maupun pengujian (Rani,dkk, 2006).

Untuk menghubungkan komponen pernyataan posisi (PP) dan komponen data (D), penulis menggunakan komponen jaminan (J) berupa tanggapan capres Prabowo atas fakta tentang korupsi yang diasosiasikan seperti kanker berstadium empat. Komponen jaminan yang menggunakan pandangan para ahli terkait pernyataan posisi dapat dikategorikan sebagai komponen jaminan dengan kadar ketajaman tinggi (Robertshaw \& Campbell, 2013). Penulis dalam data 2 menilai bahwa Prabowo merupakan salah satu ahli politik yang dapat dijadikan rujukan untuk memperkuat argumentasinya. Komponen jaminan yang digunakan penulis dalam data 2 dapat diuji kadar ketajamannya dengan mengajukan pertanyaan-pertanyaan kritis. Walton dalam Fundamentals of Critical Argumentation (2005) menyajikan tiga pertanyaan kritis yang dapat diajukan untuk mengukur kadar ketajaman pendapat ahli, yakni (1) Apakah Prabowo berada dalam posisi sebagai orang yang mengetahui bahwa korupsi yang berada di Indonesia seperti kanker?, (2) Apakah Prabowo merupakan sumber yang jujur (dapat dipercaya atau diandalkan?), (3) Apakah pernyataan Prabowo benar atau salah? Jawaban terhadap pertanyaan-pertanyaan kritis ini akan membuat argumentasi semakin lebih kokoh dan tidak dapat dibantah oleh pembaca.

\section{Pola Pernyataan Posisi-Data 1-Data 2- Jaminan (PP-D1-D2-J)}

Pola argumentasi pada tajuk rencana yang memuat komponen pernyataan posisi (PP), data kesatu (D1), data kedua (D2), dan jaminan (J) dapat dikategorikan sebagai pola argumentasi yang cukup lengkap. Pola argumentasi (PA2) dengan komponen D2 dan komponen J, pada paragraf argumentasi tajuk rencana menjadikan paragraf argumentasi tersebut lebih terperinci. Pola tersebut dapat dilihat pada paragraf argumentasi berikut.

\begin{tabular}{|l|l|l|l|}
\hline $\begin{array}{l}\text { Paragraf } \\
\text { Argumentasi }\end{array}$ & \multicolumn{2}{|l|}{$\begin{array}{l}\text { Komponen } \\
\text { Argumentasi }\end{array}$} & $\begin{array}{l}\text { Pola } \\
\text { Argu } \\
\text { ment } \\
\text { asi }\end{array}$ \\
\hline $\begin{array}{l}\text { Kalau dana } \\
\text { untuk } \\
\text { membangun } \\
\text { kebutuhan }\end{array}$ & $\begin{array}{l}\text { Kalau dana } \\
\text { untuk } \\
\text { membangun } \\
\text { kebutuhan }\end{array}$ & $\begin{array}{l}\text { Pern } \\
\text { yata } \\
\text { an }\end{array}$ & $\begin{array}{l}\text { PP- } \\
\text { D1- } \\
\text { D2-J }\end{array}$ \\
\hline
\end{tabular}

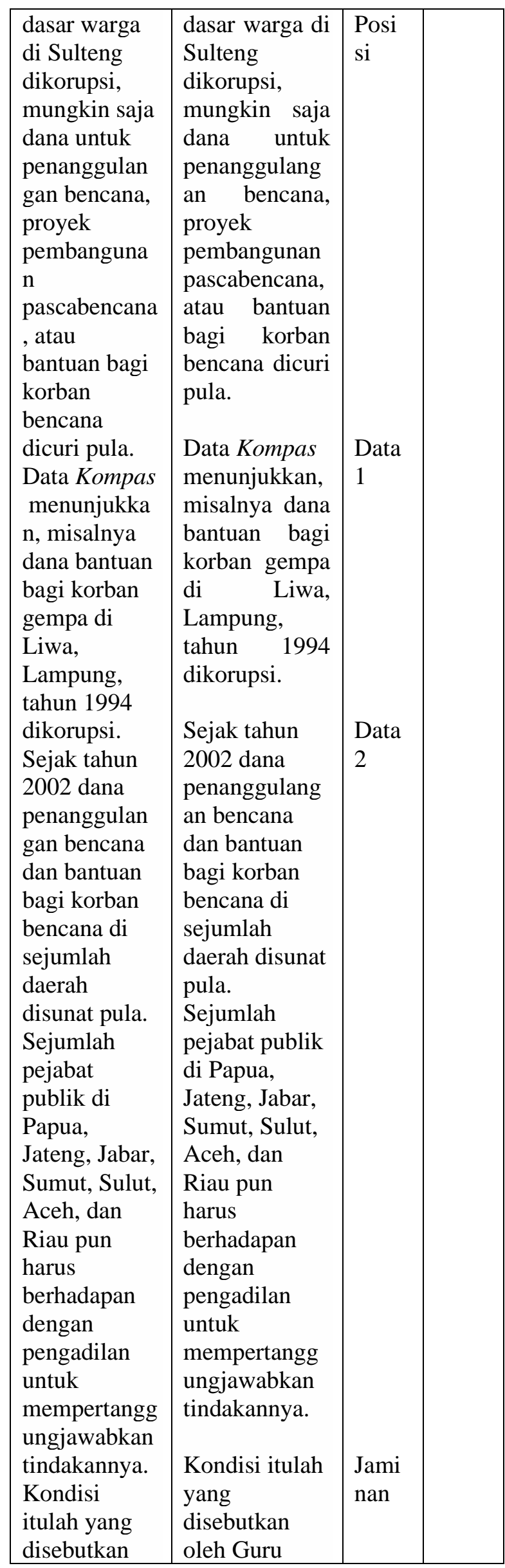




\begin{tabular}{|l|l|l|}
\hline oleh Guru & Besar & \\
Besar & Universitas & \\
Universitas & Islam Negeri & \\
Islam Negeri & Syarif & \\
Syarif & Hidayatullah, & \\
Hidayatullah, & Jakarta, & \\
Jakarta, & Azyumardi & \\
Azyumardi & Azra, sebagai & \\
Azra, sebagai & hilangnya & \\
hilangnya & empati dan & \\
empati dan & etika di & \\
etika di & kalangan & \\
kalangan & pejabat publik. & \\
pejabat & Mereka bukan & \\
publik. & hanya tidak & \\
Mereka & malu & \\
bukan hanya & mengambil & \\
tidak malu & uang negara & \\
mengambil & yang & \\
uang negara & diperuntukkan & \\
yang & membantu & \\
diperuntukka & rakyat yang & \\
n membantu & menjadi & \\
rakyat yang & korban & \\
menjadi & bencana, & \\
korban & tetapi tak & \\
bencana, & mempunyai & \\
tetapi tak & hati lagi untuk & \\
mempunyai & melindungi & \\
hati lagi & warga yang & \\
untuk & seharusnya & \\
melindungi & dilayani & \\
warga yang & & \\
seharusnya & & \\
dilayani & & \\
\end{tabular}

Kalimat pertama pada teks tajuk rencana di atas merupakan komponen PP sedangkan kalimat kedua adalah komponen data. Adapun, kalimat ketiga merupakan komponen J. Komponen PP merupakan pandangan penulis terkait fenomena korupsi dana bencana alam yang dilakukan oleh pejabat publik. Pandangan tersebut diperkuat oleh dua bukti berupa fakta (D) dimana dana bantuan bagi korban gempa di Liwa, Lampung, tahun 1994 dikorupsi dan . Sejak tahun 2002 dana penanggulangan bencana dan bantuan bagi korban bencana di sejumlah daerah disunat pula. Sejumlah pejabat publik di Papua, Jateng, Jabar, Sumut, Sulut, Aceh, dan Riau pun harus berhadapan dengan pengadilan untuk mempertanggungjawabkan tindakannyaFakta tersebut dirujuk dari media Kompas. Namun, yang menjadi permasalahan adalah bahwa sumber data tersebut masih kabur karena tidak dicantumkan tahunnya. Penulis tidak berhenti pada penggunaan $\mathrm{D}$ untuk mendukung pernyataan posisinya. Penulis juga menggunakan komponen jaminan berupa pandangan pakar yang mendukung pernyataan posisi. Hal ini sejalan dengan apa yang dikatakan Toulmin (1979) bahwa komponen jaminan menunjuk pada pernyataan-pernyataan yang dapat berupa pandangan pakar yang mendukung pernyataan posisi (PP) penulis. Pada kalimat ketiga (PA2), penulis menggunakan pandangan pakar Azyumardi Azra yang berprofesi sebagai Guru Besar Universitas Islam Negeri Syarif Hidayatullah, Jakarta.

\section{Pola Data-Pernyataan Posisi (D-PP)}

Komponen pola argumentasi data (D) dan pernyataan posisi (PP) dapat dikategorikan sebagai pola argumentasi terbalik. Artinya, pola argumentasi didahului dengan komponen data (D) kemudian diikuti dengan komponen pernyataan posisi (PP). Menurut Setyaningsih (2016) pola ini disebut juga sebagai pola induktif. Pola tersebut dapat dilihat pada paragraf argumentasi tajuk rencana sebagai berikut.

\begin{tabular}{|c|c|c|c|}
\hline $\begin{array}{l}\text { Paragraf } \\
\text { Argumentasi }\end{array}$ & $\begin{array}{l}\text { Komponen } \\
\text { Argumentasi }\end{array}$ & & $\begin{array}{l}\text { Pola } \\
\text { Argu }\end{array}$ \\
\hline $\begin{array}{l}\text { Berdasarkan } \\
\text { jajak } \\
\text { pendapat Ko } \\
\text { mpas, } \\
\text { sebanyak } \\
26,35 \text { persen } \\
\text { menganggap } \\
\text { visi-misi } \\
\text { sangat } \\
\text { penting dan } \\
64,67 \text { persen } \\
\text { menganggap } \\
\text { penting. } \\
\text { Artinya, } 90 \\
\text { persen publik } \\
\text { menganggap } \\
\text { visi-misi } \\
\text { capres itu } \\
\text { penting! } \\
\text { Sebanyak } \\
51,30 \text { persen } \\
\text { responden } \\
\text { pun ingin } \\
\text { tahu apa } \\
\text { sebenarnya }\end{array}$ & $\begin{array}{l}\text { Berdasarkan } \\
\text { jajak } \\
\text { pendapat Ko } \\
\text { mpas, } \\
\text { sebanyak } \\
26,35 \text { persen } \\
\text { menganggap } \\
\text { visi-misi } \\
\text { sangat } \\
\text { penting dan } \\
64,67 \text { persen } \\
\text { menganggap } \\
\text { penting. }\end{array}$ & $\begin{array}{l}\text { Perny } \\
\text { ataan } \\
\text { Posisi }\end{array}$ & D-PP \\
\hline
\end{tabular}




\begin{tabular}{|l|l|l|l|}
\hline visi dan misi & responden & & \\
yang akan & pun ingin & & \\
dibawa & tahu apa & & \\
pasangan & sebenarnya & & \\
capres & visi dan misi & & \\
& yang akan & & \\
& dibawa & & \\
& pasangan & & \\
& capres. & & \\
\hline
\end{tabular}

Penulis dalam paragraf argumentasi tajuk rencana di atas mengedepankan komponen data (D) yang pada awal argumentasi. Data yang digunakan penulis adalah jajak pendapat Kompas yang menyatakan bahwa sebanyak 26,35 persen menganggap visi-misi sangat penting dan 64,67 persen menganggap penting. Elemen data tersebut memiliki kadar ketajaman tinggi karena berdasarkan pada hasil jajak pendapat (Robertshaw \& Campbell, 2013). Berpedoman pada data tersebut, penulis kemudian memberikan pernyataan bahwa 90 persen publik menganggap visi-misi capres itu merupakan hal yang penting yang ingin dibawa capres dan cawapres. dalam debat. Pernyataan posisi penulis tersebut dapat dikategorikan sebagai pernyataan posisi berupa fakta Seyler (2019). Lebih lanjut, Robertshaw \& Campbell (2013)menyatakan bahwa pernyataan posisi tersebut memiliki kadar ketajaman tinggi karena berupa fakta empiris.

\section{Kesimpulan}

Argumentasi merupakan salah satu bentuk tulisan yang berusaha menyakinkan pembaca untuk bertindak atau melakukan sesuatu dengan menggunakan bukti-bukti atau alasan. Argumentasi yang baik adalah argumen yang dapat menyakinkan pembaca mengenai permasalahan yang ditemukan dalam kehidupan bermasyarakat. Proses Penulisan argumentasi harus mempertimbangkan pola-pola penulisan sehingga dapat membuat pembaca menjadi paham dan yakin.

Ada empat pola dalam penulisan tajuk rencana media daring Kompas.id. Keempat pola tersebut antara lain, pola pernyataan posisi-data (PP-D), pola pernyataan posisi-data-jaminan (PPD-J), pernyataan posisi-data 1-data 2-jaminan (PP-D1-D2-J), dan pola data-pernyataan posisi (D-PP). Pola pernyataan posisi-data (PP-D) merupakan pola yang paling dominan digunakan dalam penulisan tajuk rencana media daring Kompas.id. Pola tersebut dapat juga dikatakan sebagai pola deduktif.

\section{Daftar Pustaka}

Keraf, Gorys. (2007). Argumentasi dan Narasi. Jakarta: PT Gramedia Pustaka Utama.

Sumadirian, AS Haris.(2004). Menulis Artikel dan Tajuk Rencana. Simbiosa Rekatama Media: Bandung.

Dorothy U. Seyler \& Allen Brizee. (2019). Read, Reason, and Write (12th ed.). McGraw HillEducation: New York.

Kedaulatan, H., Roni, R., \& Anggara, F. (2015). Analisis Isi Tajuk Rencana tentang Korupsi di Surat Kabar. Jurnal Ilmu Komunikasi. Vol. 13(1), 78-95.

Moleong, L. J. 2017. Metodologi Penelitian Kualitatif. Bandung: Ramaja Rosdakarya.

Padiatra, A. M. (2018). Ketika Pers Bicara Korupsi: Analisis Tajuk Rencana Harian Pedoman pada Awal Orde Baru 1969 1974. Paradigma, Jurnal Kajian Budaya. Vol. 15(2), 103-117.

Rani, Abdul., dkk (2006). Analisis Wacana: Sebuah Kajian Bahasa dalam Pemakaian. Malang: Bayumedia Publishing.

Robertshaw, B., \& Campbell, T. (2013). Constructing Arguments: Investigating preservice Science Teachers' Argumentation Skills in a Socio-Scientific Context. Science Education. International. Vol. 24(2), 195211.

Setyaningsih, Y. (2016). Pola Argumen Paragraf Argumentatif Pada Artikel Jurnal Terakreditasi Bidang Ekonomi (Perspektif Stephen Toulmin). Adabiyyāt: Jurnal Bahasa Dan Sastra. Vol. XV(2), 136-156.

Sudaryanto. (2015). Metode dan Aneka Teknik Analisis Bahasa: Pengantar Penelitian Wahana Kebudayaan Secara Linguistis. Yogyakarta: Sanata Dharma University Press.

Walton, D. (2005). Fundamentals of critical argumentation. Fundamentals of Critical Argumentation. New York: Cambridge University Press.

Wiyanti, E., \& Dinihari, Y. (2017). Analisis Kohesi Anafora dan Katafora pada Tajuk Rencana Koran Kompas. BAHASTRA. Vol 37(2), 9-23. 